\title{
LICHENS OF NORTH AMERICA
}

IRWIN M. BRODO, SYLVIA DURAN SHARNOFF and STEPHEN SHARNOFF. 2001. Yale University Press, New Haven and London, in collaboration with the Canadian Museum of Nature, Ottawa. xxiii +821 pp., 821 b/w +927 colour illustrations. ISBN 0300-08249-5 (cloth). CAN \$105.00 (US \$69.95). Available from the Nature Saskatchewan Bookshop.

It is difficult to find words that adequately express this triumph of scientific publication. "Magnificent" or "spectacular" come to mind but hardly do justice to the breathtaking experience of first viewing the cover on arrival from the publisher. The words of another reviewer that "This volume is the twenty first century lichen equivalent of Audubon's Birds of North America" are no exaggeration. This is a book to treasure. There is something in it for everyone, from members of the lay public who will appreciate it for the beauty of the colour plates, to the professional taxonomist who will find it to be the most complete, illustrated and scientifically up-to-date lichen flora for any continent. This is one of those rare books which will be just as appropriately found on the coffee table as on the laboratory bench. It is a steal at the price. All naturalists will appreciate the infinite care that the authors and publishers have taken with the production of this superb volume.

Irwin (Ernie) Brodo is an internationally respected botanist, recently retired, and now Emeritus Research Scientist at the Canadian Museum of Nature, Ottawa. He has published monographs and many papers on lichens from North America, and his wide experience on the biology of lichens is reflected in the text. Sylvia and Stephen Sharnoff provide the photographic expertise and readers may recognize some plates from previous articles in National Geographic, Smithsonian and Discover magazines. It is a tragedy that Sylvia Sharnoff, who was in many ways the instigator of the project, did not live to see the publication of her work.
Lichens are something of an enigma. Although often quoted as the textbook example of symbiosis, they are relatively understudied. They are, of course, an association of an alga and a fungus but look like neither partner grown alone. Most algae are aquatic, so phycologists have shown little interest in this terrestrial partnership. The fungus is the dominant partner in terms of biomass but lichens are photosynthetic and therefore behave more like plants than fungi, which absorb their food from dead or living plant tissues. For these reasons, mycologists have not had much time for lichens either, despite the fact that there are about 13,500 species of fungi worldwide that occur only in lichens. In North America, there are around 3,600 species of lichens, of which 1,050 of the most common are keyed out in this book, another 450 are discussed in the text and 804 are illustrated in the magnificent colour plates. There can no longer be any excuse to ignore these fascinating organisms.

The book has two parts, the first of which, comprising fourteen chapters, deals with lichen biology, ecology, distribution and human interest. The style of writing makes the text easy to read, with much of the technical detail confined to figure headings. Among the largest chapters are those on lichen structure and reproduction but those on their unique physiology and chemistry are no less intriguing. Chapters on lichen substrate ecology and the contributions that lichens make to various ecosystems emphasize their importance to biological diversity and conservation. Many people will 
find the two chapters on the use of lichens by people and in pollution monitoring to be particularly interesting. The final three chapters in this section provide information that is pertinent to getting the most out the second part of the book.

The second part, The Guide to Lichens, comprises the bulk of the text. It commences with a key to eleven morphological groups of lichens. Each of these groups has a key to the genera and to many individual species. The keys are refreshingly easy to use, and when there is a possibility of confusion, taxa are keyed out more than once. When appropriate, each genus has a key to its own species and others with which it might be confused, a brief description and notes on chemistry, habitat and other genera with which they might be mistaken. The latter is especially useful as there has been much splitting of lichen genera of late, resulting in superficially similar species being found in different genera. Each species also has its own brief description, notes on chemistry, habitat and comparisons with other, related species. Most have a beautiful colour plate which is of such quality that it will mostly confirm the success of the keying out process at a glance. (The authors let us in to the secrets of their photographic mastery in the first part of the book). Most species also are provided with a small map of North America showing their distribution.

Lichens of North America replaces Hale's How to Know the Lichens, the only other relatively modern guide to lichens for the continent. ${ }^{1}$ That field guide is now out of date and does not include any crustose species. Field guides of more local interest are Mosses, Lichens and Ferns of Northwest North America and Plants of the Western Boreal Forest and Aspen Parkland, the former being the more comprehensive but neither dealing with same range of species for the prairie provinces as Lichens of North America ${ }^{2,5}$ Weighing in at almost eight pounds Lichens of North America is, most decidedly, not a field guide. There are already calls for the keys to be made available in a smaller format for field use. Why not a condensed version of the text to make a true field guide? We must hope. McCune and Geiser prove that such a venture is possible. ${ }^{3}$ While limited to the macrolichens of the Pacific Northwest, theirs is a high quality field guide with photographs also by the Sharnoffs.

For those interested in the basic biology of lichens there is another recent, attractive, very inexpensive and much smaller book, Lichens, which deals with many of the same topics in the first part of Lichens of North America, often from a somewhat different perspective. ${ }^{4}$

I hope readers will have gathered that I cannot praise this book highly enough. This is a book destined to become a classic of its genre.

Reviewed by John Sheard, Emeritus

Professor, Department of Biology, University of Saskatchewan, Saskatoon, SK

1. HALE, M.E. (1979) How to Know the Lichens. Wm. C. Brown Company, Dubuque, Iowa. viii + 246 pp. ISBN 0-697-04763-6 (paper). US\$38.35.

2. JOHNSON, D., L. KERSHAW, A. MACKINNON \& J. POJAR (1995) Plants of the Wcstern Boreal Forest and Aspen Parkland. Lone Pine Publishers, Edmonton. 392 pp. ISBN 155105-058-7 (paper). CAN\$ 24.95.

3. MCCUNE, B. \& L. GEISER (1997) Macrolichens of the Pacific Northwcst. Oregon State University Prcss, Corvallis, a co-publieation with the U.S.D.A. Forest Scrvice. xiv + 386 pp. ISBN 0-87071-394-9 (paper). US\$ 25.95.

4. PURVIS, W. (2000) Lichens. Smithsonian Institution, Washington, in association with the Natural History Muscum, London. 112 pp. ISBN I-56098-879-7 (paper). CAN\$ 14.95.

5. VITT, D.H., J.E. MARSH \& R.B. BOVEY (1988) Mosscs, Lichens and Ferns of Northwest North America. Lone Pine Publishers, Edmonton. 296 pp. ISBN 0-919433-41-3 (paper). CANS 26.95 . 